\title{
Chemical Composition and Nutritional Value of Mature and Young Fruiting-Bodies of Pleurotus Pulmonarius Produced On Andropogon Gayanus Straw and Khaya Ivorensis Sawdust
}

\author{
*Okwulehie, I. C.; *Urama Judith And Okorie, D. O. \\ *Department of plant Sciences and Biotechnology, Michael Okpara University of Agriculture, Umudike \\ Department of Chemistry, Michael Okpara University of Agriculture, Umu
}

\begin{abstract}
Pleurotus. Pulmonarius was cultured in the laboratory of the Department of plant Sciences and Biotechnology, Michael Okpara University of Agriculture, Umudike. The mycelium of the mushroom was bulked up on guinea corn grains and was used to produce fruit-bodies on Andropogon gayanus straw and Khaya invorensis sawdust. The Chemical composition and nutritional values of the young and mature fruit-bodies evaluated. The nutrient composition in terms of the crude oil, protein, ash, total carbohydrate content mineral and vitamins contents were analyzed, and these were found out to vary dependent upon the stage of fruit-body development and substrate types. The moisture content was at maximum at immature stage and decreased during further development of the mushroom while the ash and fibre contents showed an opposite trend. The highest ash and fibre contents were obtained from the matured fruit-bodies and the lowest in the young fruitbodies. Similarly the fats and protein contents of the mature fruit-bodies were higher than those of the young fruit-bodies. However the carbohydrate contents of the mushroom fruit-bodies were neither influenced by the substrates nor their stages of development. There was no significant difference between the proximate compositions of the fruit-bodies harvested from Andropogon gayanus straw and those from Khaya invorensis. The fruit-bodies were equally rich in Niacin, Thiamine, Ascorbic acid and Riboflavin. However the concentrations of the vitamins (in $\mathrm{mg} / \mathrm{lo0g}$ ) were more in the fruit-bodies harvested from A. gayanus straw than those from K. invorensis sawdust. In each case however, matured fruit-bodies had higher contents of the vitamins than young fruit-bodies. The result of the analyses shows that P. pulmonarius fruit-bodies contained minerals (Potassium, Sodium, Magnesium, Phosphorus and Calcium) and bio-active compounds (Alkaloids, Phenol, Tannin, Saponin and Hydrogen cyanide) in varying quantities. and mineral elements (Potassium, Sodium, Magnesium, Phosphorus and Calcium). Andropogon straw produced fruit-bodies with higher Potassium, than those from Khaya sawdust and this mineral occurred more in the matured fruit-bodies than in young ones in each case. The other minerals were low and did not show any defined trend in both the substrate and in the stages of development. Similarly, Alkaloids, contents of both matured and young fruit-bodies and from the two substrates were higher than the rest of the bioactive compounds respectively. The results of the investigation were discussed in relation of the best stage of the fruit-bodies for consumption and best substrate for the cultivation of the mushroom.
\end{abstract}

Key words: Chemical composition, nutritional value Pleurotus pulmonarius Matured fruit-bodies, young fruitbodies

\section{Introduction}

Mushrooms are fleshy noticeable fruiting-bodies of fungi, typically produced above the ground on soil or other food sources. The word mushroom is most often applied to those fungi belonging to the Division Basidiomycotina and a few members of the Division Ascomycotina). The fruiting -bodies of most mushrooms are shaped like an umbrella with central stalk (stipe) supporting a cap (pileus), which bears gills (lamellae) that produce spores on the lower side. In some species e.g Pleurotus, the stipe may be absent especially those growing on wood (Jose et al; 2002). As fungi, mushrooms lack chlorophyll and therefore cannot make their own food using solar energy. Instead, they have the ability to use the available substrates in nature by breaking down lignocellulosic compounds. They are therefore, saprophytes or parasites.

The use of mushroom as food in Nigeria is probably as old as civilization, (Ayodele, and Okhuoya, 2009). In the ancient days, mushrooms were gathered from the wild and eaten. The edible mushrooms were identified by associating them with the places they grow, the seasons of growth and also, the type of dead trees they grow on. However, there are iso of families who have perished after eating meals of poisonous mushroom such as Amanita Species. Such deaths have in no way, made many communities in the rural area shy away from eating mushrooms (Zoberi, 2000). Mushrooms with their flavour, texture, nutritional value and high productivity have been identified as an excellent food source to alleviate poverty in developing country (Eswaran and Ramabadram, 2000). Mushrooms have been evaluated for their nutritional status on the basis of 
their chemical and proximate compositions. Cultivated and wild mushrooms contain reasonable amounts of proteins, carbohydrate, minerals, fibers and vitamins, (Stamets, 2000). Furthermore, mushrooms are low in calories, sodium, fats and cholesterol.

Edible mushrooms have also been considered to have medicinal value and to be devoid of undesirable effects. They may be eaten as meat substitutes and used as flavourings in foods, soups and sauces. They also contain large amount of vitamins and minerals. (Oie, 2003, Okwulehie et al; 2007,).

Oyster mushroom contains substances which lower the cholesterol level in serum and liver of rats (Okwulehie et al; 2007).

Okwulehie and Odunze (2004b) reported that Auriculania judae, P. squarrosulus, and Russula species were found to contain appreciable amounts of alkaloids, phenols, saponins and flavournoids. Alkaloids have powerful effects in animal physiology and are of interest in pharmaceutical industries for drug manufacture (Edeoga and Gomina, 2000). The present investigation is aimed at growing the edible mushroom $P$. pulmonarius using sawdust of Khaya invorensis and Andropogon gayanus straw; to evaluate the nutritive and phytochemical values of the mushroom, and find out the stage at which the mushroom contain more nutrient and recommend them to be consumed at that stage.

\section{Materials And Methods}

The spawn used for the research work was supplied from diplomat farms and services limited, Faculty of Agriculture, Teaching and Research Farms, Rivers State University of Science and Technology, Port Harcourt.

The substrates, sawdust of Khaya invorensis and straw of Andropogon gayanus used for the cultivation of $P$. pulmonarius. were moisturized, heaped and covered to allow for fermentation process. The Andropogon straw substrate chopped into about $10 \mathrm{~cm}$ average lengths and soaked overnight in clean water (Sharma, 2003). The substrates were drained and $200 \mathrm{~kg}$ weighed into $15 \times 30 \mathrm{~cm}$ of polyethylene bags. The polybags containing the substrates were pasteurized for one hours at $100^{\circ} \mathrm{C}$ in a gas-heated drum. (Okwulehie and Okoro, 2013)

After cooling, the substrates were inoculated with equal quantities of the grain-spawn. The bags were placed in wooden chambers and covered by rapping them with thick paper to allow for full colonization of the substrate by mycelia. After 4days they were transferred to wooden racks in the cropping room.

\section{Data Collection}

Fruiting of the mushroom commenced on the different substrates 12 days after inoculation and the first flush was harvested two days afterwards. The collected fruit-bodies were arranged according to their stages of development into young and matured, i.e. while young the pileus of the fruit-bodies appear like a small ball, while the mature fruit-bodies have fully open pileus (cap).

\section{Proximate analysis}

The determination of the total dry matter, protein, crude oil and ash contents of the young and mature fruit-bodies were separately done according to AOAC, 1995 procedures on dry matter basis. In other words, the dry matter content was analyzed at $65^{\circ} \mathrm{C}$ in an oven. Analysis of protein content was done according to the Kjeldahl method with a conversion ratio of 6.25 (Manzi, et al: 1999). Analysis of crude oil content was done by Soxhlet extraction with hexane, while ash content was analysis was by incineration of samples at $550^{\circ} \mathrm{C}$. Total carbohydrates were calculated as the residual difference after subtracting protein, crude oil and ash contents on dry matter basis of the fruit-bodies samples. The total energy of $100 \mathrm{~g}$ of the fruit-bodies samples was calculated using the following equations (Manzi et al: 2004).on the basis of edible weight Kalmis et al: (2011). Energy, $\mathrm{kcal}=4$ (protein content $\mathrm{g}+$ carbohydrates content, $\mathrm{g})+9$ (crude oil content, $\mathrm{g}$ )

Energy, $\mathrm{kj}=17$ (protein content $\mathrm{g}+$ carbohydrates content, $\mathrm{g})+37$ (crude oil content, $\mathrm{g}$ )

\section{Mineral Content determination}

The concentration of mineral elements in the fruit-bodies of Potassium, Sodium, Magnesium, Phosphorus and Calcium were determined using the wet digestion extraction method according to Nivozamsky et al; (1983).

\section{Phytochemical contents \\ Quantitative estimation of the Chemicals:}

Each value is the mean of three replicate determinations \pm standard deviation.

Determination of Alkaloids

Five grams $(5 \mathrm{~g})$ of the dry powdered sample was used to determine the alkaloids contents of the mushroom following the method of Harborne (1973). The alkaloid was expressed as percentage, i. e. 
\% Alkaloids: weight of residue $\quad$ x 100

weight of sample- 1

\section{Determination of Flavonoids:}

About $5 \mathrm{~g}$ of the dry powdered sample was used to determine of Flavonoids according (Boham and Kocipai, 1994). The sample was mixed with $100 \mathrm{mls}$ of $2 \mathrm{~m} \mathrm{HCl}$ at room temperature. The solution was boiled for $30 \mathrm{~min}$ with water bath, cool and filtered. $20 \mathrm{mls}$ of Ethyl Acetate was added to the filtrate and filtered again with a weighed filter paper. The filter paper was oven dry, cool and weighed

\% Flavonoids: weight of residue $\quad$ 100

$$
\text { Weight of sample } 1
$$

\section{Determination of tannin}

The method of Okeke and Elekwa, (2003) was used for tannin determination using $5 \mathrm{~g}$ of the sample shaken with $50 \mathrm{mls}$ of $\mathrm{H}_{2} \mathrm{O}$ and and left to stand for $30 \mathrm{~min}$. The solution was filtered and $2 \mathrm{mls}$ of the filtrates was introduced into a test tube and $3 \mathrm{mls}$ of $0.1 \mathrm{M} \mathrm{Fecl}_{3}$ and $2 \mathrm{ml}$ of potassium faro cyanide were added. Addition of $46 \mathrm{mls}$ of water was done. It was filtered again and $1 \mathrm{ml}$ of the filtrate was used to read the absorbance at 710nm within $10 \mathrm{~min}$

\section{Determination of saponins}

Saponins determination was carried out using (Harborne, 1973) method, Five (5) g of the sample was boiled with $100 \mathrm{mls}$ of $20 \%$ ethanol in a water bath for $1.30 \mathrm{~min}$ and filtered while still hot. The filtrate was collected and heated for $30 \mathrm{~min}$, in $40 \mathrm{mls}$ of ether then poured into a separating funnel, the lower part of the filtrate in the separating funnel was collect and $60 \mathrm{mls}$ of n-butanol was added and the upper layer/part was collect while the lower part was discarded, the filtrate was evaporated to dryness using steam Bath at $70^{\circ} \mathrm{C}$. in an oven cooled and weighed.

\section{Determination of phenol content}

The total phenol content was determined using (Harborne, 1973) method. The fat free $0.2 \mathrm{~g}$ sample was boiled for $15 \mathrm{mins}$ with $50 \mathrm{ml}$ of ether for the extraction of phenol. five $\mathrm{ml}$ of the extract was pipetted into a $50 \mathrm{ml}$ flask and $10 \mathrm{ml}$ of distilled water was added also $2 \mathrm{ml}$ of ammonium hydroxide solution and $5 \mathrm{ml}$ of concentrated amyl alcohol were added and made up to mark and left to react for 30min for color development. The absorbance of the solution was read at $505 \mathrm{~nm}$ wave length using a spectrophotometer.

\section{Determination of vitamins content}

The contents of five vitamins in the mushroom fruit-bodies namely niacin, thiamine, ascorbic acid and riboflavin were by the spectrophotometric method (AOAC), 1980. The powdered samples were determined extracted by EDTA/TCA extraction method and the extracts read off at different wavelengths using the spectrophotometer.

\section{Results}

The result of the investigation on the nutritive (Proximate) composition of the mature and young fruitbodies of the mushroom is summarized in Table 1. The result indicates that the moisture content was at maximum at immature stage (21.88 \pm 1.33 and 25.88 \pm 0.23 in SDK and ADS respectively) and lowers in the young fruit-bodies (17.35 $\pm 0.8319 .94 \pm 0.11$ in SDK and ADS respectively) while the ash and fibre contents showed an opposite trend. The highest ash and fibre contents $(8.54 \pm 0.09,7.71 \pm 0.11$ and $7.52 \pm 0.06$, $6.64 \pm 0.02$ in SDK and ADS respectively) and lower in young fruit-bodies (5.89 $\pm 0.64,4.49 \pm 0.03$ and $5.26 \pm$ $0.06,3.89 \pm 0.04$ in SDK and ADS respectively)) Similarly the fats and protein contents of the mature fruitbodies obtained in SDK and ASD, (4.32 $\pm 0.11,7.06 \pm 0.10$ and $3.89 \pm 0.04,8.51 \pm \mathbf{0 . 1 0}$ were higher than those of the young fruit-bodies obtained in SDK and ASD, $(3.31 \pm 0.06,4.61 \pm 0.10$, and $1.46 \pm 0.02,4.08 \pm 0.10$ ) However the carbohydrate contents of the mushroom fruit-bodies were neither influenced by the substrates nor their stages of development. There was no significant difference between the proximate composition of the fruitbodies harveste from Andropogon gayanus straw and those from Khaya invorensis.

Table 1: Proximate composition of fruit bodies

\begin{tabular}{|l|l|l|l|l|}
\hline Parameters & $\begin{array}{l}\text { Young Fb On } \\
\text { Sdk }\end{array}$ & $\begin{array}{l}\text { Mature Fb On } \\
\text { Sdk }\end{array}$ & Young Fb On Asd & $\begin{array}{l}\text { Mature Fb On } \\
\text { Asd }\end{array}$ \\
\hline Moisture (\%) & $21.88 \pm 1.33$ & $17.35 \pm 0.83$ & $25.88 \pm 0.23$ & $19.94 \pm 0.11$ \\
\hline Ash (\%) & $5.89 \pm 0.84$ & $8.54 \pm 0.09$ & $5.26 \pm 0.06$ & $7.52 \pm 0.06$ \\
\hline Fibre (\%) & $4.49 \pm 10.03$ & $7.71 \pm 0.11$ & $3.89 \pm 0.04$ & $6.64 \pm 0.02$ \\
\hline Fats And Oil (\%) & $3.31 \pm 0.06$ & $4.32 \pm 0.11$ & $1.46 \pm 0.02$ & $3.89 \pm 0.04$ \\
\hline
\end{tabular}




\begin{tabular}{|l|l|l|l|l|}
\hline Protein $(\%)$ & $4.61 \pm 0.10$ & $7.06 \pm 0.10$ & $4.08 \pm 0.10$ & $8.51 \pm 0.10$ \\
\hline Total Cho (\%) & $59.83 \pm 1.22$ & $55.68 \pm 1.00$ & $59.43 \pm 0.14$ & $53.99 \pm 0.25$ \\
\hline Energy (Kcal) & $287.75 \pm 0.21$ & $289.84 \pm 1.02$ & $269.18 \pm 2.10$ & $283.01 \pm 0.51$ \\
\hline Energy (Kj.) & $1217.95 \pm 0.24$ & $1226.42 \pm 0.18$ & $1133.69 \pm 0.11$ & $1197.93 \pm 0.32$ \\
\hline
\end{tabular}

Values shown represent triplicate mean \pm standard deviation $\mathrm{SDK}=$ Sawdust of Khaya ASD = Andropogon Straw

The result of the investigation on the mineral composition of the mature and young fruit-bodies of the mushroom is summarized in Figure I. Matured fruit-bodies produced on AS (Andropogon straw) yielded the highest quantity of Potassium' followed my young fruit-bodies from AS (Andropogon straw). Calcium of the mature and young fruit-bodies was appreciable but did not differ significantly. The contents of the minerals were low and did depend neither on the stage of the fruit-bodies nor on the substrates.

The result of the investigation on the Phytochemical composition of the mature and young fruit-bodies of the mushroom is summarized in Figure II. The result shows that alkaloids of the young and mature fruit-bodies produced on Khaya sawdust and Andropogon straw were high while the other bioactive chemicals were very low

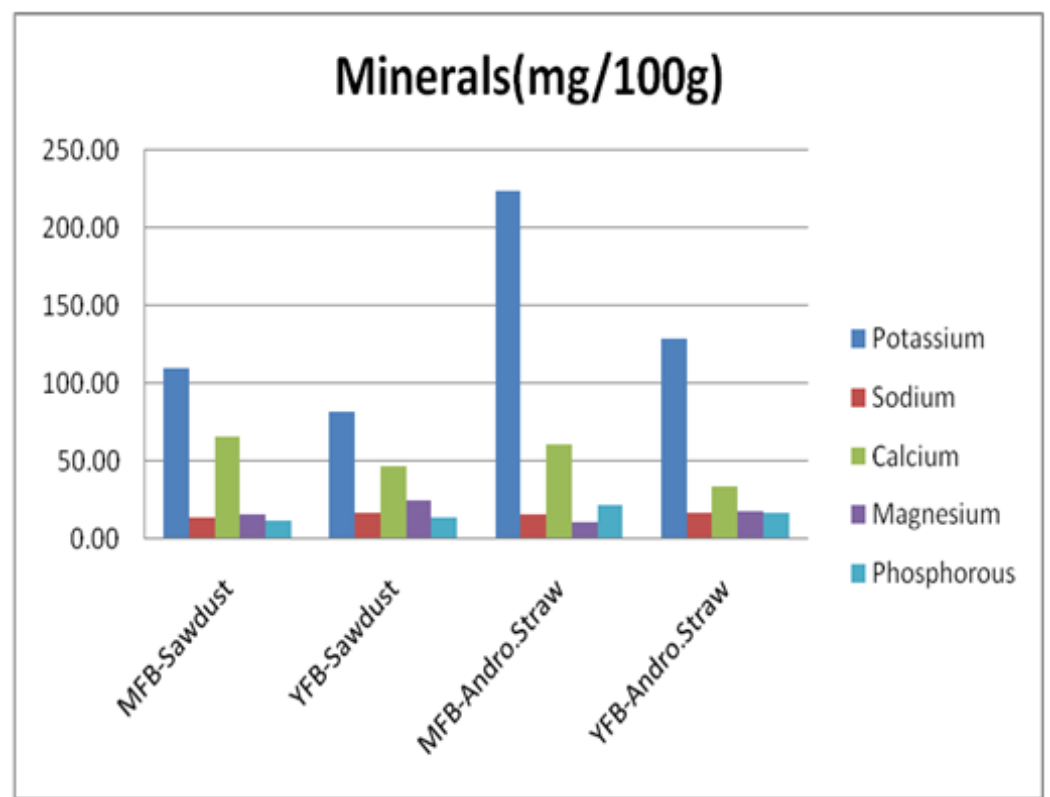

Fig. I: Mineral composition of fruit-bodies of $P$. pulmonarius Values shown represent triplicate mean \pm standard deviation

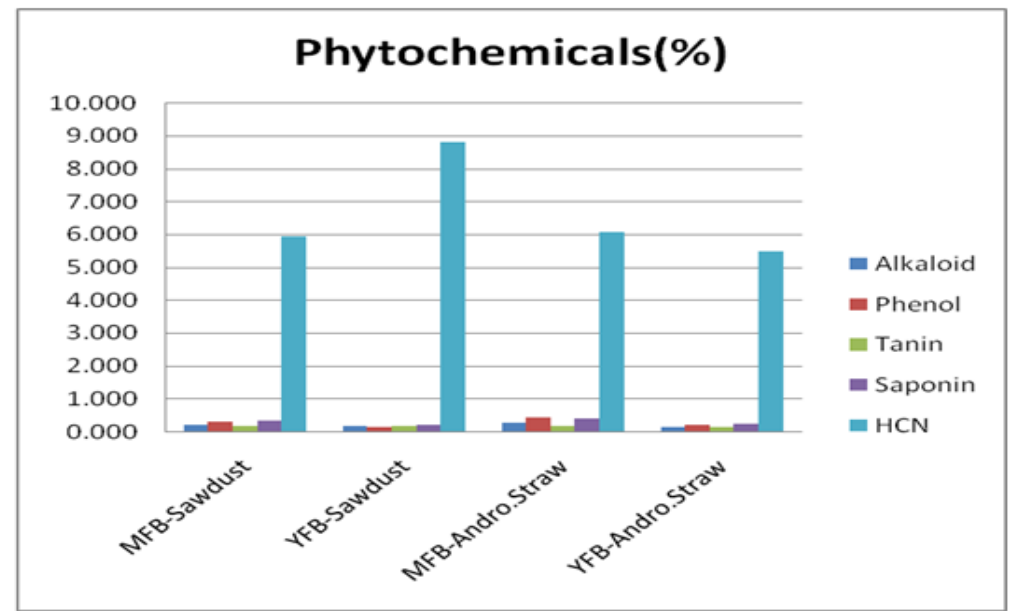

Fig. II: Phytochemical composition of $P$. pulmonarius

Values shown represent triplicate mean \pm standard deviation KEY: MFB = Matured fruit-bodies; YFB = Young fruit-bodies 


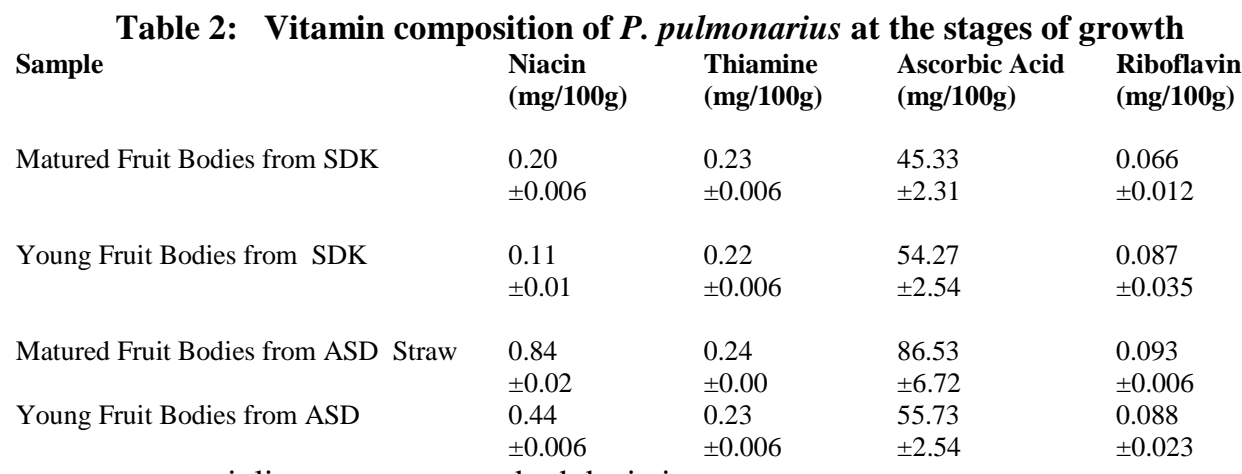

Values shown represent triplicate mean \pm standard deviation SDK = Sawdust of Khaya; AS = Andropogon Straw

Similarly the result of the vitamins contents of the fruit-bodies is shown in Table 2 . However the concentrations of the vitamins (in $\mathrm{mg} / 100 \mathrm{~g}$ ) were more in the fruit-bodies harvested from A. gayanus straw than those from Kaya. invorensis sawdust. In each case however, matured fruit-bodies had higher contents of the vitamins than young fruit-bodies.

\section{Discussion}

Considering the results of the investigation, fructification occurred in both substrates. This result supports the earlier reports by Okwulehie and Okwujiako (2008); that Pleurotus species have a high saprophytic ability and can grow well in a variety of cellulosic substrates (Thambidurai et al, 2006). However, the highest growth was recorded in Andropogon straw (Okwulehie and Okwujiako, 2008).

The nutrient composition of $P$. pulmonarius as affected by maturity state and the type of substrate on which they were grown is summarized in Table 1 . The moisture content was at maximum at the immature stage irrespective of the substrate, and decreased during further development of the mushroom. This is in line with the work of Ayodele and Okhuoya, (2008). However, the young fruit bodies from Andropogon has the highest moisture content than the young fruit bodies from sawdust while the matured fruit bodies of Andropogon had the lowest moisture content in the matured fruit bodies from sawdust. This can serve as supplement to vegetable which has high moisture content (Edoga and Gomina, 2000). However, the ash content showed an opposite trend, occurring more in matured fruit-bodies and less in young fruit-bodies irrespective of the substrate. The result is in variance with that of Kalmis et al; (2011), where young fruit-bodies contained more ash than the matured ones. The highest ash and fibre contents $(7.71 \pm 0.11 \%$ and $6.64 \pm 0.02 \%$ respectively) were obtained from matured fruit bodies from sawdust and Andropogon substrates. This is possibly because of accumulation of more cellulolytic components in the mature fruit bodies. Matured fruit-bodies from ASD had the highest protein, followed by the matured fruit-bodies from SDK, while the young fruit-bodies had low protein. This result suggests that the fruit-bodies are better consumed when matured, and that Andropogon straw should be a preferred substrate for the cultivation of the mushroom, as reported by Okwulehie and Okwujiako, (2008). For Carbohydrate contents, the preference is neither here nor there.

For mineral contents, matured and young fruit-bodies of the mushroom produced on ASD contained more potassium than those produced on SDK, this result still projects ASD as the best substrate for the production of the fruit-bodies of the mushroom.

The Young and matured fruit-bodies of the mushroom, produced on SDK and ASD, contained little quantities of phenol, tannins, saponins and HCN, property which supports the safety of the mushroom for consumption. Similarly, the high alkaloids contents of the mushroom support the usefulness and therapeutic value of the mushroom. This is because alkaloids were ranked as the most efficient therapeutic significant plant substance (Okwu and Okwu, 2004.) According to Stray, (1998), pure isolated plant alkaloids and their synthetic derivatives are used as basic medicinal agents for analgesic and anti-spasmodic and bactericidal effects.

Matured fruit-bodies from Andropogon also had higher vitamins in $\mathrm{mg} / 100 \mathrm{~g}$ of Niacin $(0.84 \pm 0.02)$, thiamine $(0.24 \pm 0.00)$, ascorbic acid $(86.53 \pm 6.72)$ and riboflavin $(0.093 \pm 0.006)$, as opposed to the matured fruit-bodies from Khaya with Niacin $(0.20 \pm 0.006)$, thiamine $(0.23 \pm 0.006)$, ascorbic acid $(45.33 \pm 2.31)$ and Riboflavin (066 \pm 0.012$)$

This investigation has demonstrated that Andropogon straw used as a substrate for Pleurotus mushroom cultivation performs better than sawdust. The observed difference in the chemical and in the nutritive values of the fruit bodies may be due to the nutritional and chemical endowments of the substrate. Using agrowastes as appropriate substrate in cultivating $P$. pulmonarius a non-timber forest product and a product chich is considered a waste is a major option or alternative to the incineration of these wastes in order to ensure a safe and healthy environment. The vast population of Nigeria, would also have a near solution to the problem of 
protein hunger which is becoming more acute. Animal protein in the form of meat and milk are beyond the reach of low income group in the country.. Under the prevailing circumstances, exploiting agro-wastes for the cultivation of edible mushrooms would help to save the country from extreme protein hunger and contribute to the Vision 2020 .o the Nation

\section{References}

[1]. AOAC: Official Methods of Analysis of the Association of Official Analytical Chemists (1995), Method No. 920.151. Helrich K.ed. AOAC;

[2]. AOAC: Official methods of analysis of the Association of Official Analytical Chemists (1980)' Volume 1.

[3]. Ayodele, S.M. and Okhuoya, J.A., (2009). Nutrition of cultivated Psathyrella atroumbonata. Pegler, a Nigeria edible mushroom. Journal of science.105 (4): 158-159.

[4]. Boham, A.B. and A. Ckoeipai, (1994) Flavonoids and conversed tannins from leaves of Hawallan Vaccinium vaticulatum and V. calycinium pacific Sci. 48: 458-463.

[5]. Edeoga, H.O., and Gomina, (2000). Nutritional values of some non-conventional leaf vegetables of Nigeria. Journal of Economic and Taxonomic Botany 24:7-12.

[6]. Eswaran, A., and Rambadran, R., (2000). Studies on some physiological cultural and post harvest aspect of Pleurtus species. Tropical agricultural Research.12: 360-374.

[7]. glucose serum lipids and serium insulin in type 2 diabetes patients.Indian

[8]. Harborne, J. B (1973). Phytochemical methods'. Chapman and Hall, limited, London. Pp 89-131

[9]. Jose, N.; Ajith, T A. and Janardhanan, K.K, (2002). Antioxidant, Anti-inflammatory, and Antitumor Activities of Culinary Medicinal Mushroom Pleurotus pulmonarius. International Journal of Medicine. 4: 329-335.

[10]. Kalmis, E; Yildiz, H.; Ergonul, B.;Kalyoncu, F. And Solak, M. H. (2011). Chemical composition and nutritional value of a wild edible ectomycorrhizal mushroom, Tricholoma anatolicum. Turkey Journal of Biology, 35: 627-633

[11]. Manzi P, Gambelli L, Marconi S et al; (1999). Nutrients in edible ushrooms: An interspecies comperative study. Food Chemistry 65: 477-482.

[12]. Manzi P, Marconi S, Aguzzi A. (2004). Commercial mushrooms: Nutritional quality and eff ect of cooking. Food Chem 84: 201-206, Medicine resources.126 (5): 471-4.

[13]. Nivozamsky, I., Houba, V.J.G., Van Eck, R., and Van Vark, W. (1983). A novel digestion technique for multi-element plant analysis. Communication in Soil Science and Plant Analysis 14,239-248.

[14]. Oei.P., (2003). Mushroom cultivation. $3^{\text {rd }}$ edition.Bachhuys Publishers Leiden, the Netherlands, 4 P.

[15]. Okeke, C. U. and Elekwa, I. (2002). Phytochemical study of the extracts of Gongronema latifolium Benth. (Asclepiadacea), J. Health Visual Sci. 5: 47-55.

[16]. Okwu, D.E and Okwu, M. E. (2004). Chemical composition of Spondias mombin Linn. Plant parts. Journal of Sustainable Agriculture and environment 6 (2): 140-147.

[17]. Okwulehie, C.I. and Okwujiako, A.I., (2008). The use of local Nigeria substrates for the production of P. ostreatusvar Florida Eger.

[18]. Okwulehie, C.I., Nwosu, C. P. , and Okoroafor, C. J.(2007). Pharmaceutical and Nutritional prospects of two wild macrofungi foung in Nigeria. Biotechnology 6 (4): 567-572

[19]. Okwulehie, I. C. and Okoro, C. E. (2013). Assessment of the Phytochemical, Proximate, Mineral and Heavy metal constituents of some grain crop straws used in cultivating Pleurotus ostreatus var florida Eger. Journal of Pharmacy and Biological Sciences 8 (4): 43-49

[20]. Okwulehie.I.C and Odunze, E. (2004b). Evaluation of the Myco-chemial and mineral composition of some tropical edible mushrooms. Journal of Sustainable Agriculture and Environment 6 (2): 157-162

[21]. Sharma, B.B., (2003). Effects of different substrates (grain/straw) on spawn growth and yield of Oyster mushroom Pleurotus djamer (Fri) Boedijin. Journal of mycology and plant pathology. 33 (2) 266-268.

[22]. Staments, P., (2000) Growth Parameters for Gourmet and Medicinal Mushroom Species. (3 ${ }^{\text {rd }}$ Ed.) Berkeley Californis, USA: Ten Speed Press. PP 316-320.

[23]. Stray, F. (1998).The Natural Guide to Medicinal Herbs and Plants. Tigers Books International, London, pp 12-16.

[24]. Thambidurai, G., Ebeneze, E.G, Muthusamy, M., (2006).Effect of organic amendments on the sporophore production of Pleurotus species. Journal of Eco-biology 18 (2), 185-187.

[25]. Zoberi, M.H., (2000). Some edible mushrooms from Nigeria field. 38, 81-90. 